Bangladesh J. Pl. Breed. Genet., 20(1) : 33-38, 2007

\title{
GENETIC VARIABILITY, CORRELATION AND PATH ANALYSIS IN POTATO (Solanum tuberosum L.)
}

\author{
M. A. Sattar ${ }^{1}$, N. Sultana, M. M. Hossain, M. H. Rashid ${ }^{2}$ and A. K. M. A. Islam $^{3}$ \\ Department of Horticulture \\ Bangabandhu Sheikh Mujibur Rahman Agricultural University \\ Gazipur 1706, Bangladesh
}

\begin{abstract}
Genotypic and phenotypic variability, heritability, genetic advance, correlation coefficients and path coefficients analysis were done for yield and its contributing characters in 28 genotypes of potato. High heritability coupled with high genetic advance as percent of mean and high genotypic coefficients of variation were observed for number of tubers per plant, yield per plant and average weight of a tuber suggesting selection for these traits would give good response. Genotypic and phenotypic correlation of the number of tubers per plant and weight of tubers per plant were highly significant. Plant vigour, number of compound leaves per plant and number of tubers per plant, average weight of a tuber and dry matter content of tuber had high degree of positive association with tuber yield per plant. As per path analysis, average weight of tuber and total number of tubers per plant contributed maximum direct effect to tuber yield indicating their importance as selection index for yield improvement.
\end{abstract}

Key words: Potato (Solanum tuberosum L.), genetic variability, correlation coefficients, path analysis, yield

\section{INTRODUCTION}

Potato (Solanum tuberosum L.) is one of the most important food crops of Bangladesh as well as of many countries of the world. It produces more calories and protein per unit land area with minimum time and water than most of the major food crops (Upadhya, 1995). It is also a world leading vegetable crop that furnishes appreciable amount of vitamin B and vitamin C as well as some minerals (Thompson and Kelly, 1957). The progress of breeding is conditioned by the magnitudes, nature and interrelationship of genotypic and environmental variation in different characters. In that case, it becomes necessary to partition the observed variability into its heritable and non-heritable components with the help of suitable genetic parameters such as genotypic coefficients of variation $(\mathrm{GCV})$, heritability estimates and genetic advance etc. It is also useful for making a comparative study of a few characters to select the desirable ones from different genotypes. Study of correlation between different quantitative characters provides an idea of association that could be effectively utilized in selecting a better plant type in potato breeding program.

\footnotetext{
${ }^{1}$ Olericulture Division, Horticulture Research Centre, BARI, Gazipur 1701, Bangladesh; ${ }^{2}$ Tuber Crops Research Centre, BARI, Gazipur 1701, Bangladesh; ${ }^{3}$ Department of Genetics and Plant Breeding, BSMRAU, Gazipur 1706, Bangladesh
} 
The present investigation was carried out in order to study these genetic parameters which would be utilized for further improvement of potato through appropriate breeding programs.

\section{MATERIALS AND METHODS}

The investigation was carried out at the experimental field of Tuber Crops Research Centre (TCRC), Bangladesh Agricultural Research Institute (BARI), Joydebpur, Gazipur during winter season of 2004-2005. Twenty eight genotypes of potato were used in the study. Among the genotypes, 24 were of CIP origin and rests were standard cultivated varieties in Bangladesh originating in the Netherlands. The experiment was laid out in a randomized complete block design with three replications. The seed tubers were sown in $3 \mathrm{~m}$ $\times 3 \mathrm{~m}$ plots maintaining row to row spacing $60 \mathrm{~cm}$ and plant to plant in a row is $25 \mathrm{~cm}$. Fertilizers were applied at the rate of 300-200-300-120-120-10 kg N, P, K, Gypsum, Magnesium sulphate and Borax per hectare, respectively. All other cultivation practices were done as per recommendation of the TCRC. Data were recorded from 10 plants randomly selected from the plot of each replication on plant vigour, plant height, compound leaves/plant, days to maturity, number of tubers/plant, average weight of a tuber, dry matter content and yield/plant. Genotypic and phenotypic variation and coefficients of variation, broad sense heritability, genetic advance and genotypic correlation coefficients were estimated using the formula suggested by Singh and Chaudhury (1979), Miller et al. (1958), Johnson et al. (1955) and Al-Jibouri et al. (1958). Path coefficients analysis was done according to the method suggested by Dewey and Lu (1959).

\section{RESULTS AND DISCUSSION}

\section{Genetic Variability, Heritability and Genetic Advance}

The analysis of variances revealed significant differences among the genotypes for all the characters (Table 1). The mean, range, coefficients of genotypic and phenotypic variations, heritability estimates and expected genetic advance in percent of mean are shown in Table 1. The highest genotypic and phenotypic coefficients of variations were observed for yield of tubers per plant and number of tubers per plant. The characters having high GCV indicate high potential for effective selection (Burton, 1957). In the present investigation the difference between GCV and PCV were low in the characters of plant vigour, dry matter content, days to maturity indicating less environmental influence on these characters. Compound leaves per plant had moderate genotypic and phenotypic coefficients of variation, and hence this trait provide practically average chance for selection. On the contrary, dry matter content, days to maturity and average tuber weight had the least phenotypic and genotypic coefficients of variation, and hence these traits provide practically less chance for selection.

Estimates of genotypic coefficients of variation alone is not sufficient to assess the heritable variation. For more reliable conclusion, estimates of high heritability and high genetic gain should be considered together (Johnson et al., 1955). The heritable fraction of the variation provides the base to the plant breeder for selection on the basis of phenotypic performance. Heritability estimates in broad sense were more than $90 \%$ for the characters of yield of tubers per plant and number of tubers per plant, and more than $80 \%$ were observed in days to maturity, plant height and plant vigour. The heritability estimates were more than 98\% for yield of tuber per plant. 
Table 1. The mean, range and genetic parameters of variation for eight characters of the 28 potato genotypes

\begin{tabular}{|c|c|c|c|c|c|c|c|c|}
\hline Item & $\begin{array}{l}\text { Plant vigour } \\
(1-10)\end{array}$ & Plant height $(\mathrm{cm})$ & $\begin{array}{l}\text { Compound leaves/plant } \\
\text { (no.) }\end{array}$ & Days to maturity & Tubers/plant (no.) & $\begin{array}{l}\text { Average weight of } \\
\text { a tuber }(\mathrm{g})\end{array}$ & $\begin{array}{l}\text { Dry matter content of } \\
\text { tuber }(\%)\end{array}$ & Tuber yield/plant (g) \\
\hline Range & $4.33-9.50$ & $37.87-78.87$ & $8.33-13.67$ & $70.67-96.33$ & $7.6-17.60$ & $27.71-44.38$ & $13.94-18.61$ & $132-481$ \\
\hline Mean \pm SE & $6.83( \pm 0.10)$ & $55.96 \pm 0.70$ & $11.14 \pm 0.31$ & $89.54 \pm 0.41$ & $12.47 \pm 0.12$ & $34.83 \pm 0.47$ & $16.94 \pm 0.20$ & $289.70 \pm 2.19$ \\
\hline$\sigma^{2} \mathrm{~g}$ & 1.23 & 66.63 & 0.94 & 30.83 & 7.91 & 17.33 & 1.15 & 7770 \\
\hline$\sigma^{2} p$ & 1.49 & 80.42 & 3.65 & 35.44 & 8.32 & 23.52 & 2.28 & 7905 \\
\hline $\mathrm{GCV}$ & 16.21 & 14.59 & 8.72 & 6.20 & 22.56 & 11.95 & 6.32 & 30.43 \\
\hline PCV & 17.87 & 16.03 & 17.15 & 6.65 & 23.14 & 13.92 & 8.91 & 30.69 \\
\hline $\mathrm{h}^{2} \mathrm{~b}(\%)$ & 82.26 & 82.86 & 25.88 & 87.00 & 95.09 & 73.68 & 50.28 & 98.30 \\
\hline GA (\% Mean) & 30.28 & 27.35 & 9.14 & 11.92 & 45.33 & 21.13 & 9.23 & 62.15 \\
\hline F- value & $* *$ & $* *$ & $*$ & $* *$ & $* *$ & $* *$ & $* *$ & $* *$ \\
\hline
\end{tabular}

* Significant at $5 \%$ level of probability, ** indicates significant at $1 \%$ level of probability.

$\sigma^{2} \mathrm{~g}=$ Genetic variance, $\sigma^{2} \mathrm{p}=$ phenotypic variance, $\sigma^{2} \mathrm{e}=$ environmental variance, $\mathrm{GCV}=$ genotypic coefficient of variation, $\mathrm{PCV}=$ phenotypic coefficient of variation, $\mathrm{h}^{2} \mathrm{~b}=$ heritability in broad sense, $\mathrm{GA}(\%$ Mean) $=$ genetic advance in percentage of mean .

Table 2. Genotypic $\left(r_{\mathrm{g}}\right)$ and phenotypic $\left(r_{\mathrm{p}}\right)$ correlation coefficients among yield and different yield contributing characters in potato

\begin{tabular}{|c|c|c|c|c|c|c|c|c|}
\hline Character & & $\begin{array}{l}\text { Plant height } \\
(\mathrm{cm})\end{array}$ & $\begin{array}{c}\text { Compound } \\
\text { leaves/plant (no.) }\end{array}$ & Days to maturity & $\begin{array}{c}\text { Tubers/ } \\
\text { plant (no.) }\end{array}$ & $\begin{array}{l}\text { Average weight } \\
\text { of tuber }(\mathrm{g})\end{array}$ & $\begin{array}{l}\text { Dry matter content } \\
(\%) \text { of tuber }\end{array}$ & $\begin{array}{l}\text { Tuber yield/plant } \\
(\mathrm{g})\end{array}$ \\
\hline \multirow[t]{2}{*}{ Plant vigour (1-10) } & $r_{g}$ & 0.299 & $0.494 *$ & 0.320 & $0.360^{*}$ & 0.087 & $0.496^{*}$ & $0.463^{*}$ \\
\hline & $r_{p}$ & 0.325 & 0.274 & 0.259 & $0.304 *$ & 0.075 & $0.494 *$ & $0.484 *$ \\
\hline \multirow[t]{2}{*}{ Plant height (cm) } & $r_{g}$ & & $0.504 * *$ & 0.314 & 0.019 & -0.182 & 0.183 & 0.187 \\
\hline & $\mathrm{r}_{\mathrm{p}}$ & & 0.220 & 0.274 & 0.016 & -0.192 & 0.163 & 0.166 \\
\hline \multirow[t]{2}{*}{ Compound leaves/plant (no.) } & $r_{g}$ & & & $0.737 *$ & 0.233 & $0.384 *$ & $0.420 *$ & $0.364 *$ \\
\hline & $r_{p}$ & & & $0.349 *$ & 0.120 & 0.029 & 0.215 & 0.197 \\
\hline \multirow[t]{2}{*}{ Days to maturity } & $r_{g}$ & & & & -0.159 & $0.337 *$ & 0.273 & $-0.592 * *$ \\
\hline & $r_{p}$ & & & & -0.153 & 0.248 & 0.154 & $-0.590^{* *}$ \\
\hline \multirow[t]{2}{*}{ Tubers/plant (no.) } & $\mathrm{r}_{\mathrm{g}}$ & & & & & $0.364 *$ & $0.454 *$ & $0.915^{* *}$ \\
\hline & $r_{p}$ & & & & & $0.308^{*}$ & 0.284 & $0.896^{* *}$ \\
\hline \multirow[t]{2}{*}{ Average weight of a tuber (g) } & $r_{g}$ & & & & & & $0.450 *$ & $0.780^{* *}$ \\
\hline & $\mathrm{r}_{\mathrm{p}}$ & & & & & & 0.281 & $0.965^{* *}$ \\
\hline \multirow[t]{2}{*}{ Dry matter content of tuber $(\%)$} & $r_{g}$ & & & & & & & $0.473^{*}$ \\
\hline & $\begin{aligned} r_{p} \\
r_{p}\end{aligned}$ & & & & & & & $0.469 *$ \\
\hline
\end{tabular}

Table 3. Path coefficients analysis showing direct (bold) and indirect effects of yield contributing characters towards yield in potato

\begin{tabular}{|c|c|c|c|c|c|c|c|c|}
\hline Character & $\begin{array}{l}\text { Plant vigour } \\
(1-10)\end{array}$ & $\begin{array}{l}\begin{array}{l}\text { Plant height } \\
(\mathrm{cm})\end{array} \\
\end{array}$ & \begin{tabular}{|c|}
$\begin{array}{c}\text { Compound leaves /plant } \\
\text { (no.) }\end{array}$ \\
\end{tabular} & Days to maturity & $\begin{array}{l}\text { Average weight of a } \\
\text { tuber }(\mathrm{g})\end{array}$ & $\begin{array}{c}\begin{array}{c}\text { Tubers/plant } \\
\text { (no.) }\end{array} \\
\end{array}$ & $\begin{array}{c}\text { Dry matter content } \\
(\%)\end{array}$ & $\mathrm{rg}_{\mathrm{g}}$ with yield \\
\hline Plant vigour (1-10) & 0.053 & -0.022 & -0.023 & 0.229 & 0.121 & -0.035 & 0.140 & $0.463 *$ \\
\hline Plant height $(\mathrm{cm})$ & 0.008 & -0.001 & -0.005 & 0.078 & 0.009 & 0.068 & 0.030 & 0.187 \\
\hline Compound leaves/plant (no.) & 0.037 & -0.001 & 0.052 & -0.020 & 0.157 & -0.002 & 0.141 & 0.364 \\
\hline Days to maturity & 0.002 & -0.092 & -0.038 & 0.057 & -0.259 & -0.180 & -0.082 & $-0.592 * *$ \\
\hline Average weight of a tuber (g) & 0.079 & -0.001 & -0.012 & -0.024 & 0.533 & 0.300 & 0.040 & $0.915 * *$ \\
\hline Tubers/plant (no.) & 0.059 & 0.017 & -0.020 & 0.029 & 0.090 & 0.608 & -0.003 & $0.780 * *$ \\
\hline Dry matter content of tuber (\%) & -0.004 & 0.039 & 0.347 & 0.129 & -0.012 & -0.004 & -0.022 & $0.473 *$ \\
\hline
\end{tabular}

Dry matter content of tuber $* \%$ indicated significant at $5 \%$ and $1 \%$ level of probability, respectively

Residual effect $=0.2014, \mathrm{r}_{\mathrm{g}}$, Genotypic correlation 
The genetic advance was also equally high as compared to heritability for the characters mentioned. So, all the characters with high heritability were equally effective for selection. Yield of tubers per plant, number of leaves per plant, plant vigour and plant height had high heritability values, and hence these characters are very much important to be considered by a breeder for selection. In addition, the characters like number of leaves per plant and yield had high genetic advance along with high heritability. Therefore, these three characters are much more important for selection with a view to developing high yielding varieties. Number of compound leaves per plant had heritability estimate of 25.88 with low genetic advance in percent of mean. So, this character may not be considered important. Likewise, dry matter content had also low genetic advance (9.23\%) which is considered less effective for selection. Panse (1957) suggested that effective selection may be done for the characters having high heritability accompanied by high genetic advance which is due to the additive gene effect. He also reported that low heritability accompanied with genetic advance is due to non-additive gene effects for the particular character and would offer less scope for selection because of the influence of environment. Desai and Jaimini (1997) also reported that tuber yield, number of stem, number of leaves, maturity, shoot fresh weight, number of tubers and average tuber weight had high genotypic coefficients of variation, high heritability and high genetic advance irrespective of environments.

\section{Correlation Coefficients}

Genotypic and phenotypic correlation coefficients between yield and its contributing characters in potato are presented in Table 2. In majority of the cases, the genotypic correlation coefficients were higher than corresponding phenotypic correlation coefficients. Higher genotypic correlations than phenotypic ones might be due to modifying or masking effect of environment in the expression of these characters under study as explained by Nandpuri et al., (1973). Johnson et al. (1955) also reported that higher genotypic correlation than phenotypic correlation indicated an inherent association between various characters. The tuber yield per plant was positively and significantly correlated with plant vigour, number of leaves per plant, number of tubers per plant, average tuber weight and dry matter content of tuber. There were significant correlations among the yield contributing characters also. Number of compound leaves per plant, number of tubers per plant and dry matter content were significantly correlated with plant vigour at genetic level. Plant height was only positively correlated with number of leaves per plant at genotypic level, while the later was only related to maturity. Days to maturity also had negative significant relationship with tuber yield per plant $\left(\mathrm{r}_{\mathrm{g}}=-0.592 * *\right.$ and $\mathrm{r}_{\mathrm{g}}=-0.590 * *$, respectively) indicating the importance of early maturing genotypes for higher yield per plant. The significant positive genotypic correlation of average weight of tuber with number of tubers per plant, yield of tuber per plant and dry matter content indicated strong genotypic relationship between them. Weight of tubers per plant showed positive relationship with yield per plant. Positive and significant relationship of yield per plant with plant vigour, number of tubers per plant and dry matter content suggested that the tuber yield can be increased by simple selection of these characters.

\section{Path Coefficients}

The results of the path-analysis in Table 3 revealed that the number of tubers per plant had the maximum direct effect on tuber yield followed by average weight of a tuber. 
Number of tubers per plant had the highest significant positive genotypic correlation with yield, which was obtained merely because of a considerably high direct effect of number of tubers per plant on yield. Number of compound leaves per plant had high positive direct effect on tuber yield, but the genotypic correlation between them was non-significant. This direct effect of number of compound leaves per plant on yield was diluted mainly due to negative indirect effect via plant height and dry matter content. Consequently, such anomalous situation suggested that a restricted simultaneous selection model could be followed to nullify the undesirable indirect effects to make proper use of the direct effect. This character showed no remarkable positive indirect effect via remaining characters on yield. The direct effect of dry matter content $(-0.022)$ on yield was negative. Dry matter content had significant positive genotypic correlation with yield, which might be due to negative indirect effect via plant height on yield. Days to maturity showed strong negative significant association with yield and had positive direct $(0.057)$ effect on yield. Strong negative association of days to maturity with yield was obtained possibly due to negative indirect effect of this character via all other characters, specially plant height $(-0.001)$ and dry matter content $(-0.022)$.

The residual effect $(0.201)$ indicated that about 80 percent of the variability in yield per plant was contributed by the eight characters studied in path analysis. This residual effect towards yield in the present study might be due to many reasons such as other characters which were not studied, environmental factors and sampling errors (Sengupta and Karatia, 1971). Within the scope of the path analysis carried out in the present investigation, it is, therefore, suggested that the number of tubers per plant and average weight of tuber weight which are the main components of yield should be given high priority in the selection programme.

\section{REFERENCES}

Al-Jibouri, H. A., Miller and H. F. Robinson, 1958. Genotypic and environmental variation and correlation in upland cotton cross of interspecies origin. Agron, J. 50: 633-637.

Burton, W. G. 1957. The influence of sprout development at planting on subsequent growth and yield. The growth of potato. Proc. of Tenth Easter School in Agril. Sci., Univ. of Nottingham, 1963. Butter Worths, London. pp. 21-29.

Desai, N. C. and S. N. Jaimini. 1997. Studies on genetic divergence in potato (Solanum tuberosum L.). J. Indian Potato Assoc. 24 (3 \& 4):154-160.

Dewey, D. R. and K. I. Lu. 1959. A correlation and path coefficients analysis of components of crested wheat grass seed production. Agron. J. 1: 515-518.

Johnson, H. W., H. F. Robinson and R. E. Comstock. 1955. Estimation of genetic and environmental variability in soybean. Agron. J., 47:314-318.

Miller, P. A., C. Willams, H. F. Robiwson and R. E. Comstock. 1958. Estimates of genotypeic and environmental variance and covariance and their implication in section. Agron. J. 50: 126-131.

Nandipuri, B. S., B. S. Singh and T. Lal. 1973. Studies on the genetic variability and correlation of some economic characters in tomato. J. Res. 10: 316-321.

Panse, V. G. 1957. Genetics of quantitative characters in relation to plant breeding. Indian J. Genet. Pl. Breed. 17: 318-28.

Sengupta, K. and A. S. Karatia.1971. Path co-efficients analysis for some characters in soybean. Indian J. Genet. 31: 290-95. 
Singh, R. K. and B. D. Choudhary. 1979. Biometrical Methods in Quantitative Genetic Analysis. Revised ed. Kalyani Publishers, New Delhi. pp. 57.

Thompson, H. C. and W. C. Kelly. 1957. Vegetable Crops. 5th Edition. Mc Graw Hill Book Company, Inc. New York, Toronto and London. pp. 611.

Upadhya, M. D. 1995. The potential of true potato seed technology for increased potato production in Bangladesh. Proceedings of the National Workshop on National Programme for True Potato Seed (TPS) in Bangladesh, May 5, 1995, Bangladesh Agricultural Research Council, Dhaka. pp.5. 